\title{
Integrated Hypoxia Signaling and Oxidative Stress in Developmental Neurotoxicity of Benzo[a]Pyrene in Zebrafish Embryos
}

\author{
Yi-Chen Lin ${ }^{1,+}{ }^{+}$Chang-Yi Wu ${ }^{2,+}$, Chin-Hwa $\mathrm{Hu}^{3}$, Tun-Wen Pai ${ }^{4,5}$, Yet-Ran Chen ${ }^{6}$ and \\ Wen-Der Wang ${ }^{1, *}$ \\ 1 Department of Bioagricultural Sciences, National Chiayi University, Chiayi City 60004, Taiwan; \\ lintina0212@gmail.com \\ 2 Department of Biological Sciences, National Sun Yat-sen University, Kaohsiung 80424, Taiwan; \\ cywu@mail.nsysu.edu.tw \\ 3 Department of Bioscience and Biotechnology, National Taiwan Ocean University, Keelung 20224, Taiwan; \\ chhu@mail.ntou.edu.tw \\ 4 Department of Computer Science and Engineering, National Taiwan Ocean University, Keelung 20224, \\ Taiwan; twp@csie.ntut.edu.tw \\ 5 Department of Computer Science and Information Engineering, National Taipei University of Technology, \\ Taipei 10608, Taiwan \\ 6 Agricultural Biotechnology Research Center, Academia Sinica, Taipei 11529, Taiwan; \\ yetran@gate.sinica.edu.tw \\ * Correspondence: wangw4@mail.ncyu.edu.tw \\ + The authors contributed equally to this work.
}

Received: 8 July 2020; Accepted: 9 August 2020; Published: 11 August 2020

check for updates

\begin{abstract}
Benzo[a]pyrene $(\mathrm{B}[\mathrm{a}] \mathrm{P})$ is a polycyclic aromatic hydrocarbon formed by the incomplete combustion of organic matter. Environmental B[a]P contamination poses a serious health risk to many organisms because the pollutant may negatively affect many physiological systems. As such, chronic exposure to $\mathrm{B}[\mathrm{a}] \mathrm{P}$ is known to lead to locomotor dysfunction and neurodegeneration in several organisms. In this study, we used the zebrafish model to delineate the acute toxic effects of $\mathrm{B}[\mathrm{a}] \mathrm{P}$ on the developing nervous system. We found that embryonic exposure of $\mathrm{B}[\mathrm{a}] \mathrm{P}$ downregulates shh and isl1, causing morphological hypoplasia in the telencephalon, ventral thalamus, hypothalamus, epiphysis and posterior commissure. Moreover, hypoxia-inducible factors (hif1 a and hif2a) are repressed upon embryonic exposure of $\mathrm{B}[\mathrm{a}] \mathrm{P}$, leading to reduced expression of the Hif-target genes, epo and survivin, which are associated with neural differentiation and maintenance. During normal embryogenesis, low-level oxidative stress regulates neuronal development and function. However, our experiments revealed that embryonic oxidative stress is greatly increased in $\mathrm{B}[\mathrm{a}] P$-treated embryos. The expression of catalase was decreased and sod1 expression increased in $\mathrm{B}[\mathrm{a}] P$-treated embryos. These transcriptional changes were coincident with increased embryonic levels of $\mathrm{H}_{2} \mathrm{O}_{2}$ and malondialdehyde, with the levels in $\mathrm{B}[\mathrm{a}] P$-treated fish similar to those in embryos treated with $120-\mu \mathrm{M} \mathrm{H}_{2} \mathrm{O}_{2}$. Together, our data suggest that reduced Hif signaling and increased oxidative stress are involved in $\mathrm{B}[\mathrm{a}] P$-induced acute neurotoxicity during embryogenesis.
\end{abstract}

Keywords: benzo[a]pyrene; neurotoxicity; oxidative stress; hypoxia-inducible factor

\section{Introduction}

The nervous system is the most complex and important signal transmission system in the animal body, playing important roles in controlling nearly every aspect of an animal's physiology and 
response to the environment. As such, the nervous system is centrally involved in signal transmission, automatic activities, cognition, memory, emotion and functional coordination of physiological systems. Development of the vertebrate nervous system begins with the process of neural induction, which refers to the specification of neuroectodermal cells that give rise to the neural plate. This process is regulated by complex interactions between Bmp, Wnt and Fgf signaling [1,2]. After neuroectodermal cells form the neural plate on the dorsal side of the embryo, the tissue is then remodeled and curls to form a neural tube along the central axis on the dorsal side of the embryo. Cells within the neural tube further differentiate to become mature neurons. Anomalies in the development of the nervous system can cause congenital mental retardation, neural tube defects, epilepsy, dementia and neurodegenerative disease; some such anomalies are caused by environmental chemical toxicants.

One major class of chemical toxicants is polycyclic aromatic hydrocarbons (PAHs), a group of semivolatile organic compounds that are ubiquitous in the environment. The widespread environmental distribution of these toxicants is because of their generation from the incomplete combustion of natural or artificial organic matter and anthropogenic plastic and petrochemicals [3,4]. Many PAHs and their epoxides are known to be highly cytotoxic, genotoxic (mutagenic and/or carcinogenic) and embryotoxic to vertebrates. Benzo[a]pyrene $(\mathrm{B}[\mathrm{a}] \mathrm{P})$ is a five-ring $\mathrm{PAH}$ that is created by the incomplete combustion of organic matter; notably, it is found in cigarette smoke and grilled and broiled foods [5]. This molecule is classified as a Group 1 carcinogen by the International Agency for Research on Cancer (IARC), meaning that it is a known human carcinogen, and it can induce cancer in multiple organs of laboratory animals [6,7]. There is no known commercial or industrial use for $\mathrm{B}[\mathrm{a}] \mathrm{P}$, and it is only purposefully produced for use in research. $\mathrm{B}[\mathrm{a}] \mathrm{P}$ is taken up by organisms from the air, water or diet [8,9]. Once taken up into cells, B[a]P induces the expression of Cytochrome p450 (CYP) monooxygenase enzymes through AhR/ARNT signaling, enhancing the catalysis of CYP-mediated metabolic reactions [10]. Research has shown that $\mathrm{B}[\mathrm{a}] \mathrm{P}$ exhibits carcinogenicity, teratogenicity, neurotoxicity and immunotoxicity in various species of experimental animals [11-14].

Many toxicants are known to damage cells by elevating the intracellular reactive oxygen species and the induction of oxidative stress has been implicated in various conditions of the nervous system, including neurodegenerative disease, attention deficit hyperactivity disorder, autism and dyslexia. Oxidative stress refers to elevated intracellular levels of reactive oxygen species (ROS) and is defined as an imbalance between free radicals and antioxidants in the cell or body [15]. In some normal physiological states, oxidative stress is known to regulate gene expression, cellular differentiation and aging-related mechanisms, among other processes [16-18]. On the other hand, oxidative stress that is induced by cellular exposure to toxicants often leads to cell and tissue damage [19,20]. ROS are derived from several intracellular sources, including mitochondria, NAD(P)H oxidase, xanthine oxidase and uncoupled nitric oxide synthase [21]. During embryogenesis, experimental enhancement or suppression of ROS alters embryonic development and growth, indicating a certain level ROS is required to regulate the normal progression of embryonic development [22]. Although excessive ROS has been implicated in the progression of Alzheimer's disease (AD), Parkinson's disease (PD) and other neurodegenerative diseases [23], it also plays an important role in the regulation of embryonic neurogenesis [24] and the dynamic control of ROS levels during embryogenesis is a key factor in neural development.

Hypoxia-inducible factors (Hifs), including Hif1, Hif2 and Hif3, function in oxygen homeostasis by regulating the genes responsible for glucose metabolism, erythropoiesis, angiogenesis, apoptosis and cell proliferation [25]. As the cell number in developing embryos increases, endogenous embryonic hypoxia stimulates the expression of Hif genes and stabilizes Hif proteins, which induce the expression of vascular endothelial growth factor (vegf) and erythropoietin (epo) to, respectively promote angiogenesis and erythrogenesis [26,27]. Additionally, Hif2a has been reported to maintain neural progenitor cell populations and promote neural differentiation by regulating survival during embryogenesis [28].

In the current study, we investigated the role of Hif signaling and oxidative stress in the neuropathology of $\mathrm{B}[\mathrm{a}] \mathrm{P}$ in developing zebrafish embryos by analyzing the expression of genes related 
to Hif signaling, examining the markers of oxidative stress. Embryonic exposure to B[a]P resulted in developmental hypoplasia of the brain, trigeminal ganglion cells and Rohon-Beard cells at $24 \mathrm{hpf}$. Moreover, reduced expression of hif1a and hif2a was coincident with the low expression of survivin and epo in $\mathrm{B}[\mathrm{a}] P$-treated embryos. Expression of genes that modulate oxidative stress and the embryonic level of $\mathrm{H}_{2} \mathrm{O}_{2}$ were also altered in $\mathrm{B}[\mathrm{a}] P$-treated embryos. These results provide novel insights into how neurological disorders may be caused by B[a]P, further delineating the molecular neuropathology of $\mathrm{B}[\mathrm{a}] \mathrm{P}$ during zebrafish embryogenesis.

\section{Materials and Methods}

\subsection{Chemicals}

B[a]P (No. B-1760) and other chemicals were purchased from Sigma-Aldrich (St. Louis, MO, USA). To eliminate the potential interference of chemical contaminants, all chemicals used in this study were of a molecular biology grade.

\subsection{Animal Care and Maintenance}

Wild-type (AB) and transgenic (Tg(elavl3:EGFP)) zebrafish were maintained in a recirculating housing system under standard laboratory conditions: $28.5^{\circ} \mathrm{C}, \mathrm{pH} 7-8,14: 10 \mathrm{~h}$ light:dark cycle. Fish were fed with commercial tropical zebrafish feed (Azoo, Taiwan) twice daily and live brine shrimp (Ocean Star International, USA) once daily. The two zebrafish strains were used in this study, AB and Tg(elavl3:EGFP), were both originally obtained from the Taiwan Zebrafish Core Facility at Academia Sinica, Taiwan and were maintained in the laboratory for more than 10 generations. Embryos were obtained through natural mating. Experimental animals were collected at the 1- to 4-cell stages and cultured in sea salt egg water $(0.0375 \%$ sea salt in deionized distilled water). All experiments involving animals were conducted in accordance with the Institutional Animal Care and Use Committee (IACUC) at National Chiayi University, which approved the animal experiments and standard operating protocols (Approval No. 104043).

\subsection{Benzo[a]pyrene Treatment and Embryo Processing}

To determine the acute toxicity of ethanol on the developing neural system, 1- to 4-cell stage embryos were transferred to a petri-dish containing sea salt egg water. Eighty embryos by 4 cells stages were used in each group to increase throughput and reduce variability. Embryos were allowed to habituate in $\mathrm{B}[\mathrm{a}] \mathrm{P}$ solutions at the following concentrations: $0 \mu \mathrm{M}$ (control, $0.1 \% \mathrm{DMSO}$ ), $10 \mu \mathrm{M}$ and $20 \mu \mathrm{M}$. To aid visualization of zebrafish development, 0.2-mM 1-phenyl-2-thiourea (Sigma-Aldrich) was used in some experiments to inhibit pigmentation at 20-22 h post-fertilization (hpf); embryos were staged as described previously [29]. The Tg(elavl3:EGFP) transgenic embryos were treated with B[a]P at concentrations of $0 \mu \mathrm{M}$ (control, $0.1 \%$ DMSO), $10 \mu \mathrm{M}$ and $20 \mu \mathrm{M}$ and their neural development was observed under fluorescence microscopy at $24 \mathrm{hpf}$. All experiments were performed with at least three independent replicates.

\subsection{In Situ Hybridization Staining}

Zebrafish embryos were exposed to $0 \mu \mathrm{M}$ (control, $0.1 \%$ DMSO), $10 \mu \mathrm{M}$ and $20 \mu \mathrm{M}$ of B[a]P since 2 hpf. Embryonic exposure to B[a]P was terminated and fixed at 12, 24 and $48 \mathrm{hpf}$ in $4 \%$ paraformaldehyde in phosphate-buffered saline (PBS) at $\mathrm{pH} 7.2$ and processed using standard protocols [30]. Antisense probes labeled with digoxigenin-UTP (Roche) were synthesized by in vitro transcription using cDNA templates encoding elavl3 [31], shh [32], epo [33] and survivin (birc5a) [34], as previously described. In situ hybridization staining was developed with NBT/BCIP substrate. Sense riboprobes served as the control for each antisense probe, all in situ staining results are shown in the Supplementary Figure S1. All imaging was performed using an Olympus BX53 upright microscope equipped with an Olympus 
DP72 Digital Color Microscope Camera. All images were processed for contrast, brightness and color using Photoshop CS3 Extended Version 10.0 (Adobe; San Jose, CA, USA).

\subsection{Embryonic MDA and Hydrogen Peroxide Measurement}

The lipid peroxidation product, malondialdehyde (MDA), is a well-established marker of oxidative stress in cells and tissues. The level of MDA was quantified spectrophotometrically at $535 \mathrm{~nm}$ on an Epoch spectrophotometer (BioTek). A calibration curve for MDA in the embryos was prepared by treating the embryos with $\mathrm{H}_{2} \mathrm{O}_{2}$ at $15,30,60,120$ and $180 \mu \mathrm{M}$. Therefore, the MDA levels were calculated as equivalents to $\mathrm{H}_{2} \mathrm{O}_{2}$ exposure concentrations $(\mu \mathrm{M})$, based on a comparison of signal to the calibration curves. Values were then compared with negative controls and expressed as a fractional increase in MDA level compared with negative control. Embryonic $\mathrm{H}_{2} \mathrm{O}_{2}$ measurements were made using the ferrous ion oxidation xylenol orange (FOX) assay [35]. Zebrafish embryos were homogenized in $0.5 \mathrm{~mL}$ ice-cold $80 \%$ methanol and centrifuged, which was followed by the collection of supernatants. The supernatants of samples and FOX reagent (100- $\mu \mathrm{M}$ xylenol orange, $250-\mu \mathrm{M}$ ferrous ammonium sulfate, $100-\mathrm{mM}$ sorbitol and $25-\mathrm{mM} \mathrm{H}_{2} \mathrm{SO}_{4}$ in methanol) were mixed in a 1:10 ratio, and the mixtures were incubated at room temperature for $30 \mathrm{~min}$ in the dark. The absorbance of the mixtures was measured at $560 \mathrm{~nm}$, and the concentration of embryonic $\mathrm{H}_{2} \mathrm{O}_{2}$ was calculated using a standard curve $(0,20,40,60,80$ and $100 \mu \mathrm{M})$.

\subsection{Real-Time Quantitative PCR}

Total RNA was extracted using Trizol reagent (), and $3 \mu \mathrm{g}$ of total RNA was reverse transcribed with MMLV high performance reverse transcriptase (Epicenter) for cDNA synthesis. Quantitative PCR reactions were performed with EvaGreen dye (Biotium) for low background and high resolution data. Quantitative RT-PCR analysis was performed, and signals were detected using the Rotor-Gene Q System (QIAGEN). Expression levels for each individual gene were normalized to the actin gene expression from the same sample. Results were analyzed by the $2^{(-\triangle \Delta C T)}$ formula, as previously described (Livak and Schmittgen, 2001). The following primers were used. actin: 5'-CACCTTGCAGCAGATGTGGA-3', 5'-AAAAGCCATGCCAATGTTGTC-3'; birc5a: 5'-CACTCCAGAAAACATGGCTAAA-3', 5'-CCATCCTTCCAGCTCTTT CA-3'; epo: 5' -TGA AGTCTGGGAAGCG ATG-3', 5'-GCATGTGTAAGCCTGAC TGG-3'; hif1a: 5'-CCTTCTGCCACT CACTGTGT-3' , 5' -CGAGGAGGGTAAGG GTTGGA-3'; hif2 $a$ : 5' -AGCTCGACT TGCTCTTGCTA-3' , 5'-CTGACAAGCT ACTGCTGAGTGA-3'; cat: 5' -AGGGCAACTGGGATCTTACA-3' , 5' -TTTATG GGA CCAGACCTTGG-3'; sod1 (Cu-SOD): 5'-GTCGTCTGGCTTGTGGAGTG-3' , 5' -TGTCAGCGGGCTAGT GCTT-3'; survivin (bir5b): 5' -AGACGTTGCCTGCTGTTTCT-3', 5' -TAGGCAATCTTCCGATGACC-3', еро: 5'-TGA TGCTGATGGT GCTGGAG-3' , 5'-GACTGGACCTCCTGAGCTTG-3' .

\subsection{Statistical Tests}

The toxicity of B[a]P on zebrafish developing neural cells was determined based on the number of neurons. All experiments were conducted in triplicate and the data were presented as the mean \pm standard deviation. Significant differences in developing neural number between the treatment groups were evaluated using on-way ANOVA, followed by Tukey's post hoc test. Values were considered statistically significant when $p<0.05$ and highly significant when $p<0.01$. All statistical analyses were performed using SPSS 21.0 (IBM).

\section{Results}

To study the toxic effects of $\mathrm{B}[\mathrm{a}] \mathrm{P}$ on the embryonic neural development of zebrafish, $\mathrm{Tg}$ (elav13:EGFP) embryos were used. In these transgenic fish, GFP is specifically expressed in neurons. We exposed Tg(elavl3:EGFP) embryos to 0.1\% DMSO (control), $10 \mu \mathrm{M}$ and $20 \mu \mathrm{M}$ B[a]P from $2 \mathrm{hpf}$ until $24 \mathrm{hpf}$. Images of B[a]P-treated live embryos at $24 \mathrm{hpf}$ did not show obvious morphological differences from the controls (Figure 1A-C). Neural development was then observed 
under fluorescent microscopy (Figure 1D-O). From the live images, we noticed that the fluorescence intensity in $\mathrm{B}[\mathrm{a}] P$-treated embryos was weaker than that in the control embryos. The number of trigeminal ganglion cells in the head and Rohon-Beard cells in the front-trunk, mid-trunk and tail regions were counted. In the head region, the numbers of trigeminal ganglion cells were $15 \pm 1.2$ in the controls, $9.3 \pm 2.2$ in $10 \mu \mathrm{M}$ B [a]P and $6.5 \pm 1.3$ in $20 \mu \mathrm{M}$ B[a]P-treated embryos (Figure $1 \mathrm{P}$ ). There were $14.7 \pm 1.7,27.8 \pm 2.1$ and $41.3 \pm 0.7$ Rohon-Beard cells in front-trunk, mid-trunk and tail region of control embryos. These numbers were reduced to $9.2 \pm 2.1,23 \pm 0.6,27.1 \pm 1.6$ in front-trunk, mid-trunk and tail region of $10 \mu \mathrm{M} \mathrm{B}[\mathrm{a}] \mathrm{P}$, and the values were $6.8 \pm 0.7,18.7 \pm 1.6$ and $19.3 \pm 2.2$ in front-trunk, mid-trunk and tail region of $20 \mu \mathrm{M}$ B[a]P treated embryos, respectively. These results indicated that the number of developing trigeminal ganglion cells and Rohon-Beard cells was significantly reduced in $\mathrm{B}[\mathrm{a}] P$-treated embryos. We further examined the development of the central nervous system in the control and $\mathrm{B}[\mathrm{a}] P$-treated embryos by in situ hybridization staining with a riboprobe against elavl3 mRNA, which is specifically expressed in telencephalon, midbrain, midbrain hindbrain boundary, midbrain hindbrain plate, hypothalamus and cranial ganglion (Figure 2A). Compared with the control embryos, the expression pattern of elval3 was obviously altered in B[a]P-treated embryos (Figure 2A-C). Compared with control embryos, the expression intensity of elavl3 in the telencephalon fore-midbrain region (Figure 2D-F, rectangular frame), hindbrain and cranial ganglion (Figure $2 \mathrm{G}-\mathrm{I}$ ) in $\mathrm{B}[\mathrm{a}] P$-treated embryos was weaker than that in the control embryos and the expression width in the hindbrain was increased in $\mathrm{B}[\mathrm{a}] P$-treated embryos (Figure 2D-F). Real time quantitative PCR assay indicated that the expression of elavl3 was does-dependently reduced in B[a]P treated embryos (Figure 2J). Taken together, our results clearly indicate that $\mathrm{B}[\mathrm{a}] \mathrm{P}$ treatment induced embryonic neurodevelopmental toxicity.

DMSO
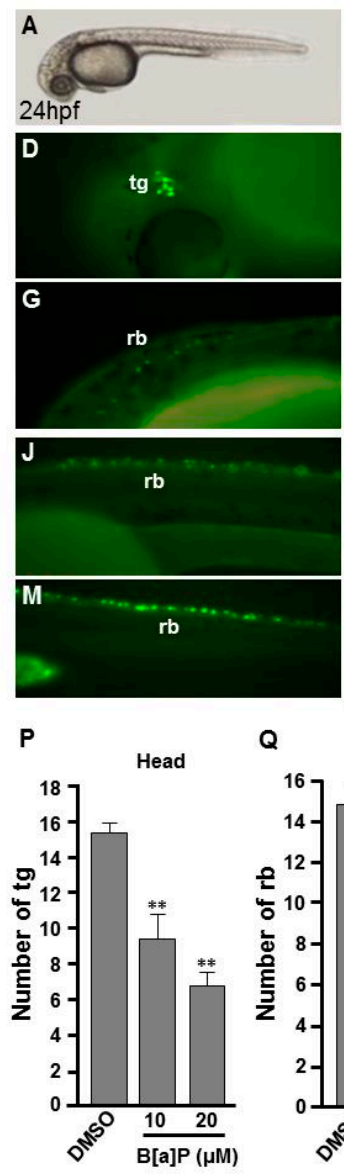

$10 \mu \mathrm{M} B[\mathrm{a}] \mathrm{P}$
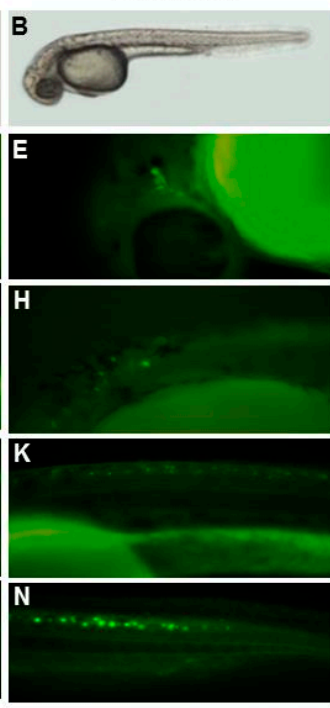

$\mathbf{R}$
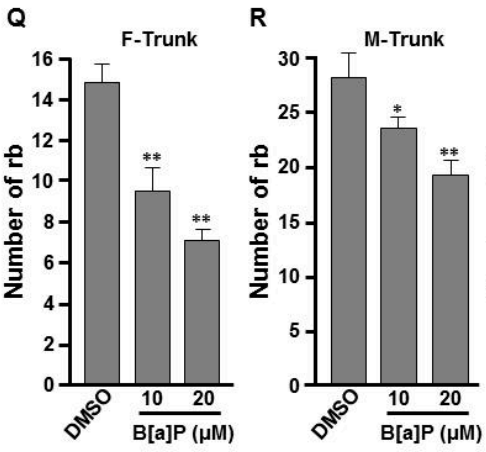

$20 \mu \mathrm{MB}[\mathrm{a}] \mathrm{P}$
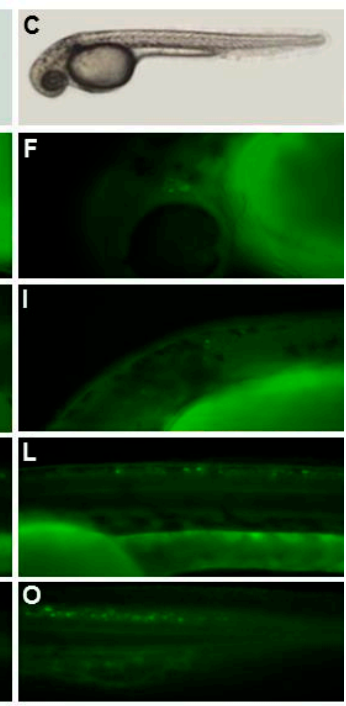

S

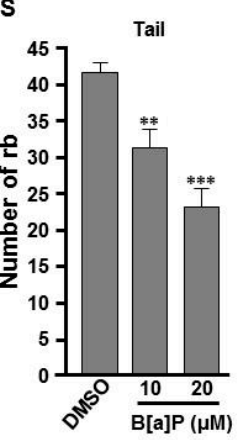

Figure 1. Developmental neurotoxicity of B[a]P revealed by the Tg(elavl3:EGFP) model. Tg(elavl3:EGFP) 
zebrafish embryos received the indicated treatments: $0 \mu \mathrm{M}$. (control, 01\% DMSO; $(\mathbf{A}, \mathbf{C}, \mathbf{F}, \mathbf{I}, \mathbf{L})$ ), $10-\mu \mathrm{M}$ $\mathrm{B}[\mathrm{a}] \mathrm{P}(\mathbf{B}, \mathbf{D}, \mathbf{G}, \mathbf{J}, \mathbf{M})$ and $20-\mu \mathrm{M}$ B[a]P $(\mathbf{C}, \mathbf{E}, \mathbf{H}, \mathbf{K}, \mathbf{N})$. (A-C) Lateral view of the live embryos at $24 \mathrm{hpf}$ after treatment with $0.1 \%$ DMSO (control; A), 10- $\mu \mathrm{M} \mathrm{B}[\mathrm{a}] \mathrm{P}(\mathbf{B})$ and $20-\mu \mathrm{M}$ B[a]P (C); (D-O) Effects of B[a]P on neurogenesis using the Tg(elavl3:EGFP) model. The embryos treated with $0.1 \%$ DMSO (control; $(\mathbf{D}, \mathbf{G}, \mathbf{J}, \mathbf{M})), 10-\mu \mathrm{M}$ B[a]P $(\mathbf{E}, \mathbf{H}, \mathbf{K}, \mathbf{N})$ and $20-\mu \mathrm{M}$ B[a]P $(\mathbf{F}, \mathbf{I}, \mathbf{L}, \mathbf{O})$ were collected at 24 hpf. Representative fluorescent images are shown for embryonic trigeminal ganglions (tg) in the head region (D-F) and Rohon-Beard cell $(\mathrm{rb})$ in the front trunk $(\mathbf{G}-\mathbf{I})$, mid-trunk $(\mathbf{J}-\mathbf{L})$ and in tail regions $(\mathbf{M}-\mathbf{O})$. (P-S) The numbers of tg cells in the head region and rb cells in front-trunk (F-trunk), mid-trunk (M-Trunk) and tail were counted from 10 embryos in each treatment group. Data are shown as mean \pm standard deviation. ${ }^{*} p<0.05,{ }^{* *} p<0.01,{ }^{* *} p<0.001$ compared with the control.

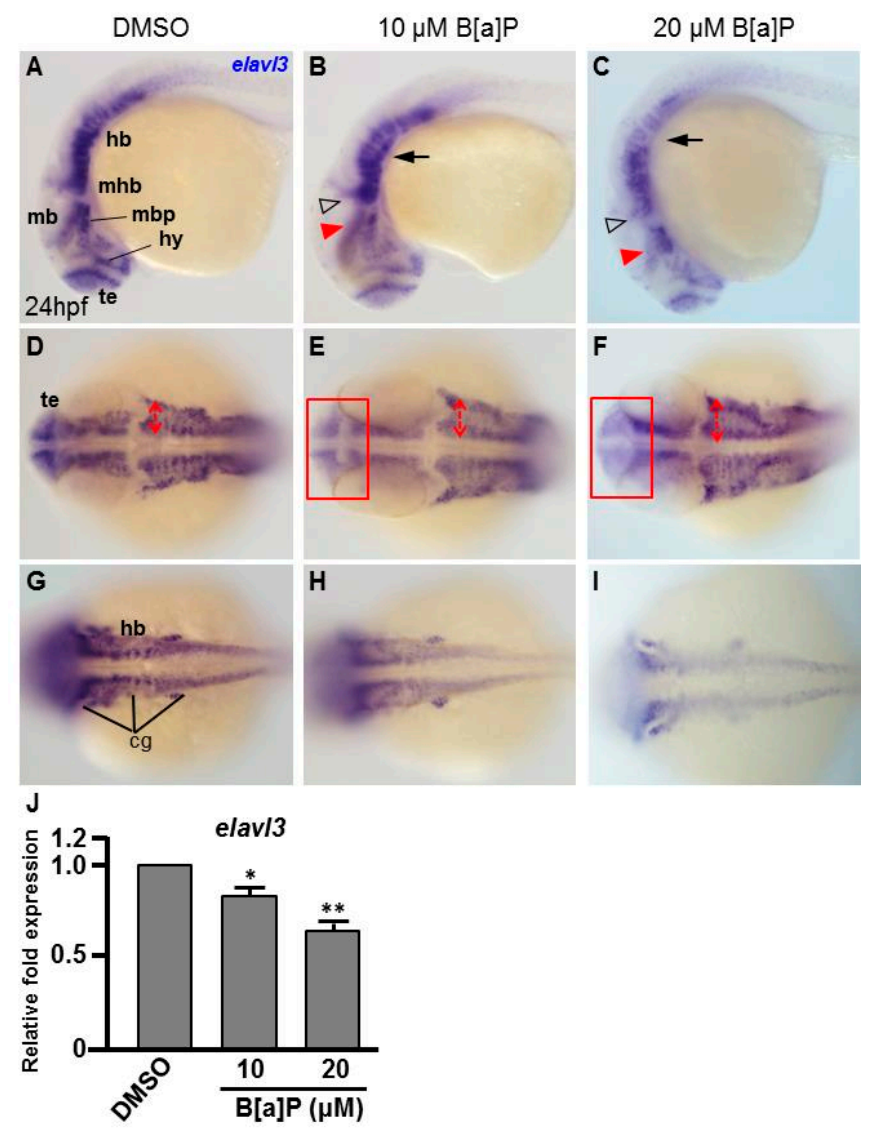

Figure 2. B[a]P-treated embryos exhibit defective nervous system development. In situ hybridization staining was performed with a riboprobe against elavl3, a marker gene specifically expressed in telencephalon (te), hypothalamus (hy), midbrain (mb), midbrain hindbrain boundary (mhb) and plate (mhp) and hindbrain (hb) of the developing brain (A). (A-I) Zebrafish embryos exposed to $0 \mu \mathrm{M}$. (control, 01\% DMSO), 10- $\mu \mathrm{M}$ B[a]P and 20- $\mu \mathrm{M}$ B[a]P were analyzed at $24 \mathrm{hpf}$. Embryos in (A-C) are shown from the lateral view; the red arrowheads indicate developmental defects in the midbrain (mb), and the hollow arrowheads indicate developmental defects in midbrain-hindbrain boundary (mhb); (D-F) Embryos are shown from the lateral view. The developing telencephalon (te; rectangles in (E,F)) was wider and the expression of elavl3 was weaker than in the control embryos; (G-I) Images are focused on the hindbrain (hb) region. The development of cranial ganglia (cg) was dose-dependently affected by B[a]P treatment; (J) Expression alteration of elavl3 in B[a]P was quantified by real-time quantitative RT-PCR (* $p<0.05,{ }^{* *} p<0.01$ compared with the control). 
3.1. Exposure of B[a]P Causes Reduced Expression of shh and islt1 in the Developing Neural System at 24 hpf

To explore the toxic mechanism of $\mathrm{B}[\mathrm{a}] \mathrm{P}$ on the developing embryonic nervous system, we first probed the expression of sonic hedgehog (shh), a signal for neurogenic induction, proliferation and neuroprotection in various cell types and islet 1 (isl1), which encodes a LIM homeodomain transcription that plays an essential role in embryogenesis. The exposure of zebrafish to B[a]P led to reduced expression of shh in mid-dicencephalic organizer, basal plate and hypothalamus (Figure 3A-C). From the lateral view, we also noticed that the expression of shh in the notochord and neural tube floor plate was more curved in $20 \mu \mathrm{M}$ B[a]P-treated embryos (Figure 3C). From the dorsal view, expression of shh was obviously reduced in the brain and notochord of B[a]P-treated embryos (Figure 3E-F). In untreated wild-type embryos, isl1 was specifically expressed in the telencephalon, ventral thalamus, hypothalamus, epiphysis and posterior commissure at $24 \mathrm{hpf}$. Its expression was significantly reduced by B[a]P treatment in the telencephalon, ventral thalamus and hypothalamus (Figure 3H-J). Surprisingly, expression of shh was expanded in ventral thalamus and dramatically reduced in the hypothalamus, epiphysis and posterior commissure of 20- $\mathrm{MM} \mathrm{B}[\mathrm{a}]$ P-treated embryos (Figure 3J). The frontal view also revealed a low expression of isl1 in telencephalon, ventral thalamus and hypothalamus (Figure $3 \mathrm{~K}-\mathrm{M}$ ). Real-time quantitative PCR was further performed to confirm the expression reduction of shh and isl1 in $\mathrm{B}[\mathrm{a}] \mathrm{P}$ treated embryos (Figure $3 \mathrm{~N}, \mathrm{O}$ ) These results serve to define the specific brain regions affected by $\mathrm{B}[\mathrm{a}] P$-induced disruption of neural development.

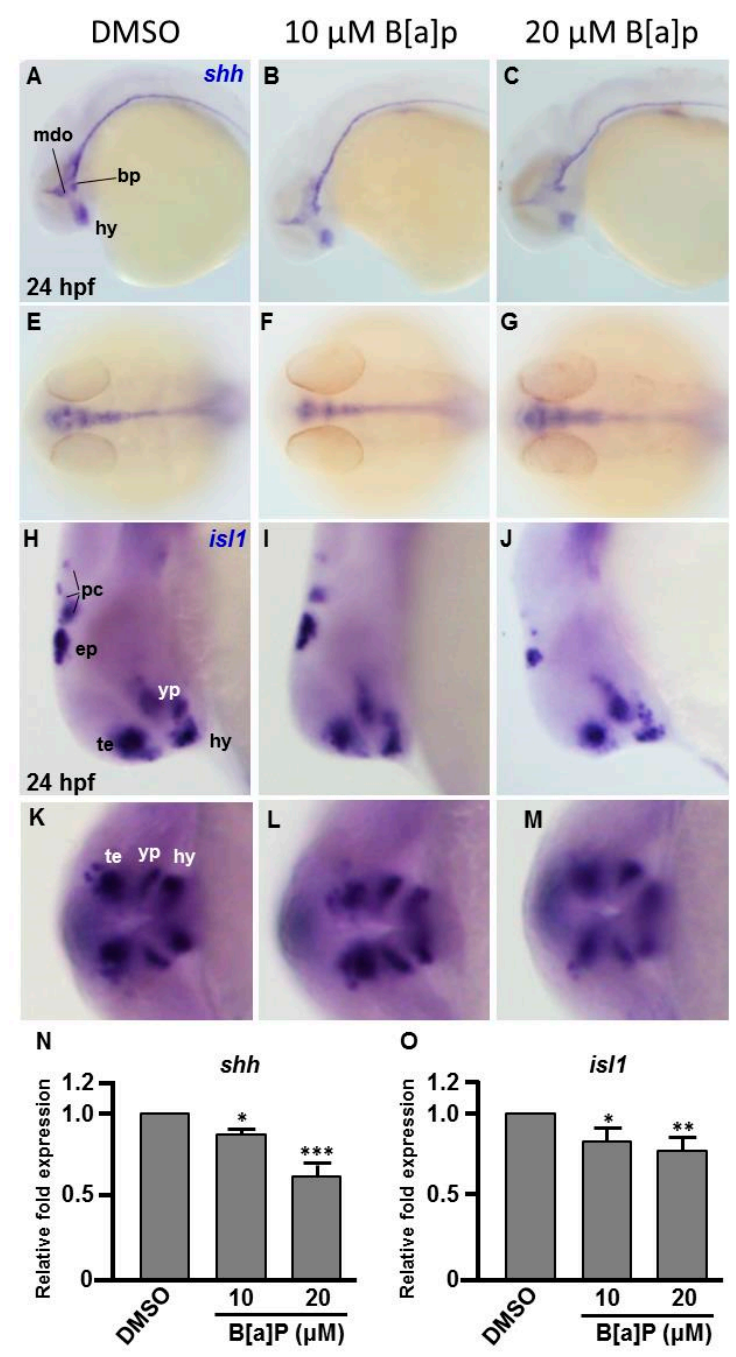

Figure 3. Expression patterns of shh and isl1 are dose-dependently affected by B[a]P exposure. Wild-type 
(AB) zebrafish embryos were treated with $0 \mu \mathrm{M}$. (control, 01\% DMSO), 10- $\mu \mathrm{M} \mathrm{B}[\mathrm{a}] \mathrm{P}$ and $20-\mu \mathrm{M}$ B[a]P. The embryos were fixed at $24 \mathrm{hpf}$. Expression of $\operatorname{sh}(\mathbf{A}-\mathbf{G})$ and isl1 $(\mathbf{H}-\mathbf{M})$ was analyzed by in situ hybridization staining. Images show the lateral view in (A-C,H-J). Images in (E-G) show the dorsal view. Images in $(\mathbf{K}-\mathbf{M})$ show the frontal view; $(\mathbf{B}, \mathbf{C})$ Expression of shh was specifically expressed in the mid-diencephalic organizer (mdo), hypothalamus (hy) and basal plate (bp) of $\mathrm{B}[\mathrm{a}] P$-treated embryos; (E-G) The expression pattern of $s h$ in the brain and floor plate (fp) in $20-\mu \mathrm{M} \mathrm{B}[\mathrm{a}] P$-treated embryos; (H-M) The development of encephalic regions was examined by in situ hybridization staining by probing for the islet1 gene (isl1) which is specifically expressed in telencephalon (te), ventral thalamus (vp), hypothalamus (hy), epiphysis (ep) and posterior commissure (pc) in embryos at $24 \mathrm{hpf}$. (N, O) Expression alteration of shh and isl1 in B[a]P was quantified by real-time quantitative RT-PCR $\left({ }^{*} p<0.05\right.$, ${ }^{* *} p<0.01,{ }^{* * *} p<0.001$ compared with the control).

\subsection{No Obvious Neural Defects Are Present in B[a]P-Exposed Embryos at $12 \mathrm{hpf}$}

To determine the embryonic timing at which $\mathrm{B}[\mathrm{a}] \mathrm{P}$ begins to affect the developing neural system, we performed in situ hybridization staining with an elavl3 riboprobe in embryos at 12 hpf. At this time point, elavl3 is expressed in cranial trigeminal ganglions cells, primary motor neurons and Rohon-Beard cells (Figure $4 \mathrm{~A}, \mathrm{D}, \mathrm{G}$ ). Based on the staining results, no obvious effects of B[a]P exposure could be observed on trigeminal cranial ganglion cells in the head region (Figure $4 \mathrm{~A}-\mathrm{C}$ ) or in primary motor neurons and Rohon-Beard cells (Figure 4D-I). These observations suggest that the neurotoxic effects of $\mathrm{B}[\mathrm{a}] \mathrm{P}$ are not present at $12 \mathrm{hpf}$, suggesting that the window of vulnerability begins at later stages.

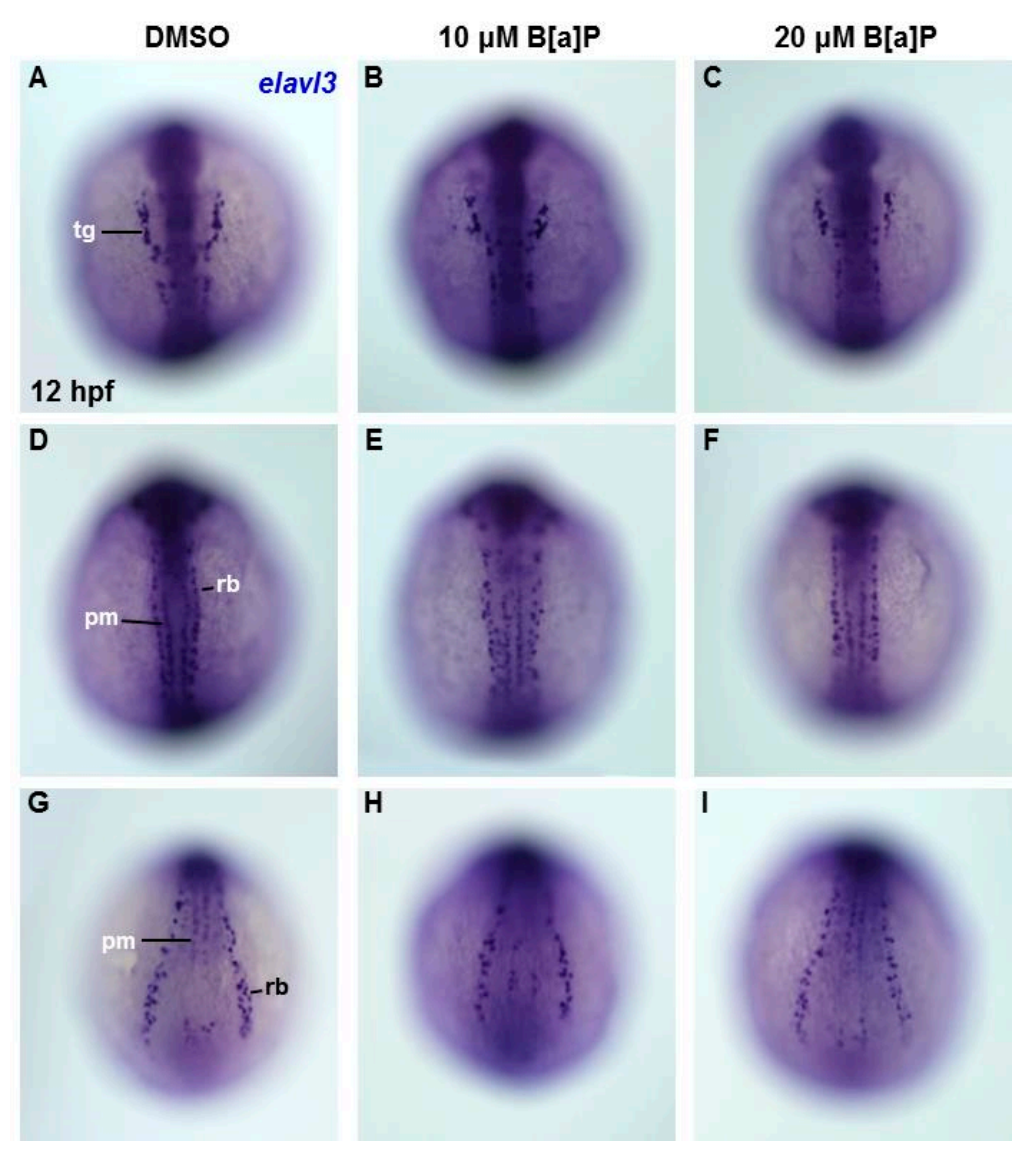

Figure 4. Lack of obvious neural cell defects in B[a]P-treated embryos at $12 \mathrm{hpf}$. In situ hybridization staining with a probe against elavl3 was performed to analyze the early development of neural cells (A-I); all images show the dorsal view. Images in (A-C) are focused on the anterior trunk; (D-F) are focused on mid-trunk region and (G-I) are focused on the tail region. tg, trigeminal ganglion; pm, primary motor neurons; rb, Rohon-Beard cells. 


\subsection{B[a]P Exposure Alters the Expression of Hypoxia-Related and Oxidative Stress-Related Genes}

Many studies have shown that the expression of Hifs and oxidative stress-related genes occurs in organisms exposed to chemical stresses [36], and the expression of these genes is also closely associated with embryonic neural development [37]. To assess whether the expression of these genes is altered by $\mathrm{B}[\mathrm{a}] \mathrm{P}$ exposure in the developing neural system, quantitative RT-PCR was performed to measure the expression of hif1a, hif2a, calatase and sod1 (encodes Cu-containing superoxide dismutase; CuSod). Interestingly, the levels of hif1a, hif2a and calatase were reduced (Figure 5A-C) and the level of sod1 was increased (Figure 5D) in B[a]P-treated embryos compared with the controls. The low expression of hif1a and hif2 $a$ was unexpected, so we further examined the expression of survivin, a target of hif $2 a$ that is known to regulate embryonic neural development. In situ hybridization results indicated that survivin was specifically expressed in the brain and neural tube of wild-type embryos at $24 \mathrm{hpf}$ (Figure 6A,D) and the expression level was obviously reduced in $\mathrm{B}[\mathrm{a}] P$-treated embryos (Figure 6B,C,E,F). The expression levels were quantified and the results confirmed that $\mathrm{B}[\mathrm{a}] \mathrm{P}$ was able to dose-dependently reduce the expression (Figure 6M). We also detected another Hif target gene, epo (Figure 6G-L), which is expressed in brain during embryogenesis and is functionally associated with neural differentiation and proliferation [38-40]. The quantitative results indicated that the expression of epo was also dose-dependently reduced by B[a]P treatment (Figure $6 \mathrm{~N}$ ), and the effect sizes at each dose were similar to those for hif2 $a$ in $\mathrm{B}[\mathrm{a}] P$-treated embryos.
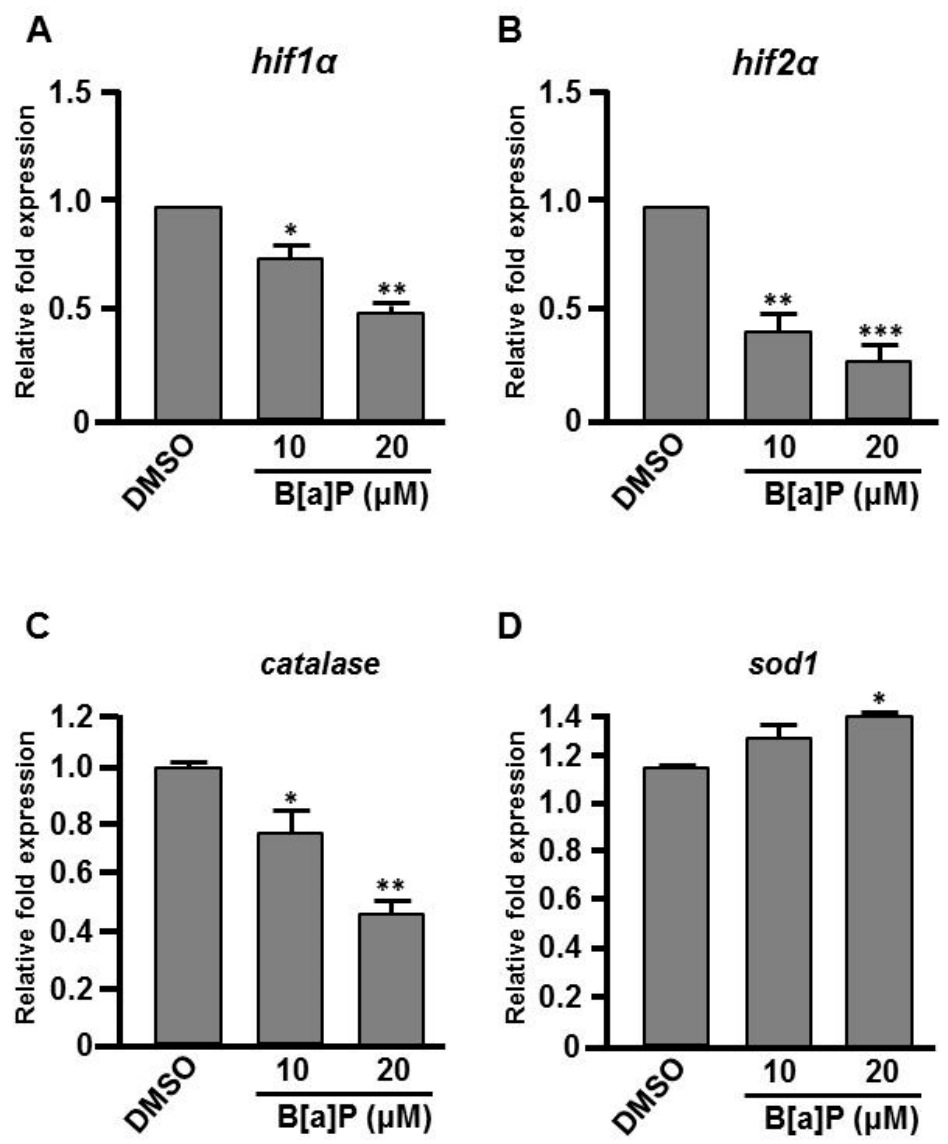

Figure 5. Expression levels of Hifs and oxidative stress-related genes are altered in $\mathrm{B}[\mathrm{a}] \mathrm{P}$ treated embryos. Zebrafish embryos were exposed to $0 \mu \mathrm{M}$. (control, 01\% DMSO), 10 and $20 \mu \mathrm{M}$ of B[a]P from 2 hpf until 24 hpf. Expression of genes encoding (A) Hif1 $\alpha,(\mathbf{B})$ Hif $2 \alpha,(\mathbf{C})$ Catalase and (D)Sod1 was examined by real-time quantitative RT-PCR. ${ }^{*} p<0.05,{ }^{* *} p<0.01,{ }^{* * *} p<0.001$ compared with the control. 


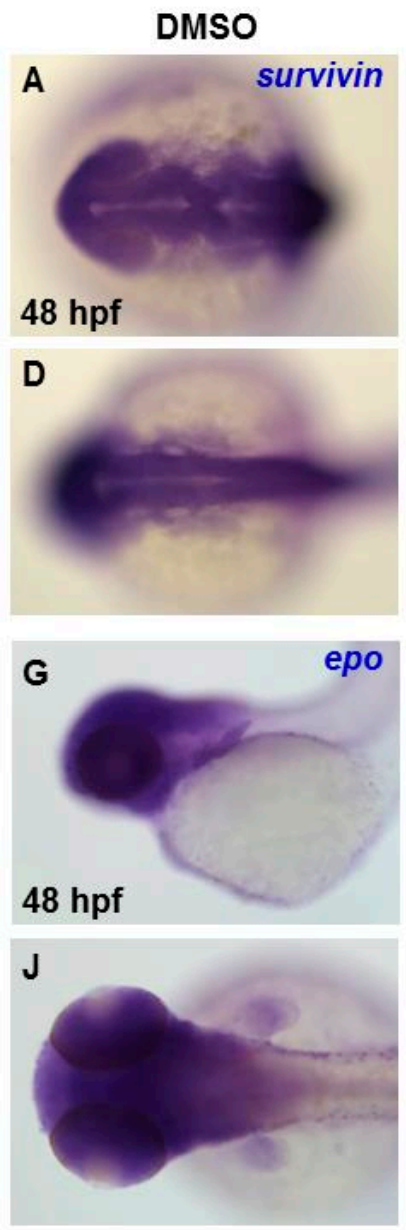

M

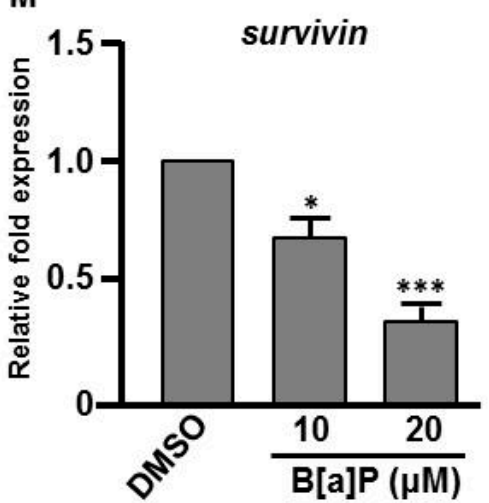

$10 \mu \mathrm{M} \quad \mathrm{B}[\mathrm{a}] \mathrm{P}$
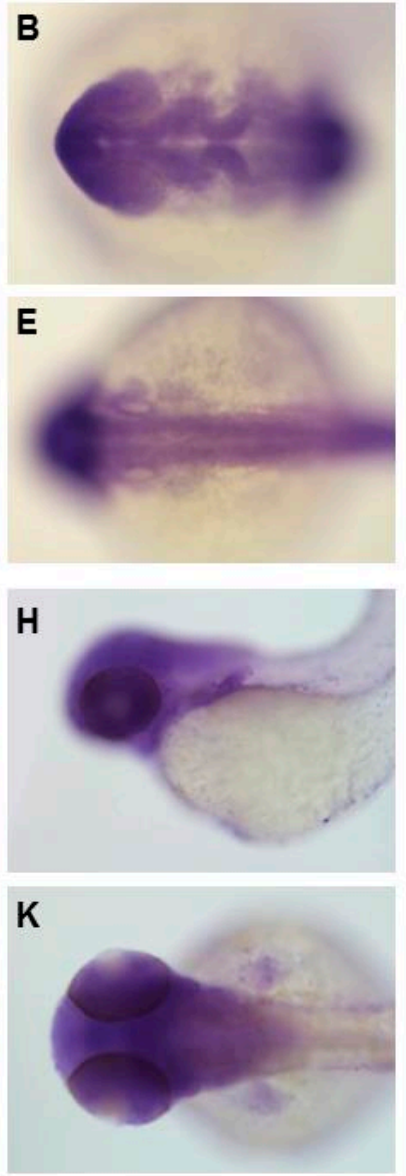

\section{N}

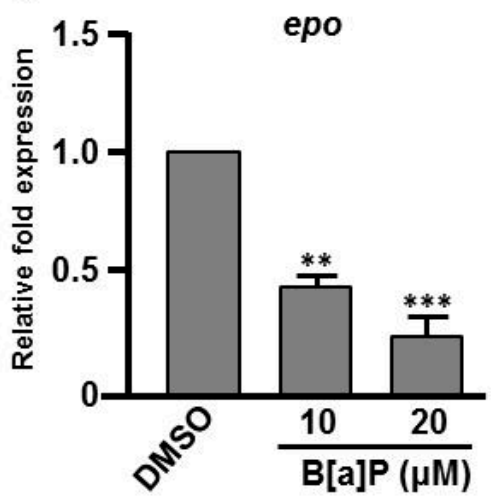

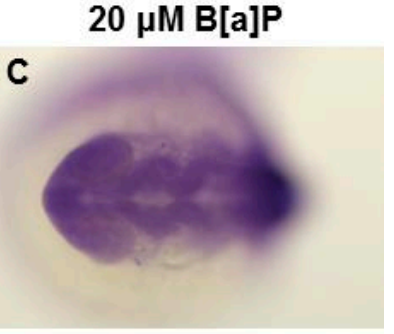
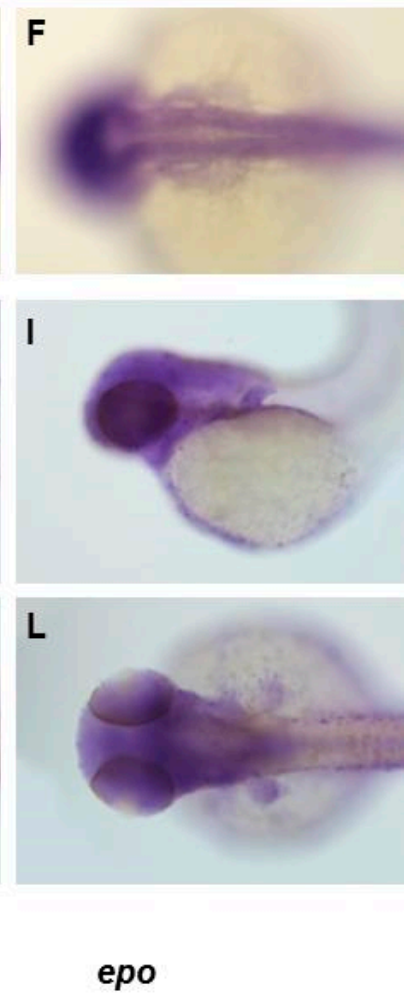
of cellular $\mathrm{H}_{2} \mathrm{O}_{2}$ result in the impairment of cells and embryogenesis [37,46]. Moreover, the levels of ROS and lipid peroxidation are influenced by a variety of enzymes. For example, catalase functions to decompose $\mathrm{H}_{2} \mathrm{O}_{2}$ to water and oxygen [46] and SOD1 (CuSod) catalyzes the dismutation of superoxide to hydrogen peroxide and oxygen [47]. Since we saw effects on the expression of catalase and sod1 in $\mathrm{B}[\mathrm{a}] P$-treated embryos (Figure $5 \mathrm{C}, \mathrm{D}$ ), we wondered whether cellular $\mathrm{H}_{2} \mathrm{O}_{2}$ and the lipid peroxidation product, MDA, may be affected in $\mathrm{B}[\mathrm{a}] P$-treated embryos. In the positive control group, we exposed zebrafish embryos to $120 \mu \mathrm{M} \mathrm{H}_{2} \mathrm{O}_{2}$ combined with $0.1 \%$ DMSO and the embryonic levels of $\mathrm{H}_{2} \mathrm{O}_{2}$ and lipid peroxidation in the embryos were detected with the FOX and MDA assays, respectively. Our results indicated that the embryonic levels of $\mathrm{H}_{2} \mathrm{O}_{2}$ and MDA were increased in $\mathrm{B}[\mathrm{a}] P$-treated embryos. Surprisingly, the levels of these ROS markers in $10 \mu \mathrm{M} \mathrm{B}$ [a]P-treated embryos were similar to the positive control embryos (Figure 7A) and the levels of both markers in 20- $\mu \mathrm{MB}$ B a]P-treated embryos were higher than those in positive control embryos. Thus, the altered expression of catalase and sod1 were coincident with high levels of $\mathrm{H}_{2} \mathrm{O}_{2}$ (Figure 7A) and lipid peroxidation products (Figure 7B) in $\mathrm{B}[\mathrm{a}] P$-treated embryos. Moreover, $\mathrm{B}[\mathrm{a}] P$-induced embryonic oxidative stress is likely to at least partially mediate the toxic effects of $\mathrm{B}[\mathrm{a}] \mathrm{P}$ on developing neural system during embryogenesis.
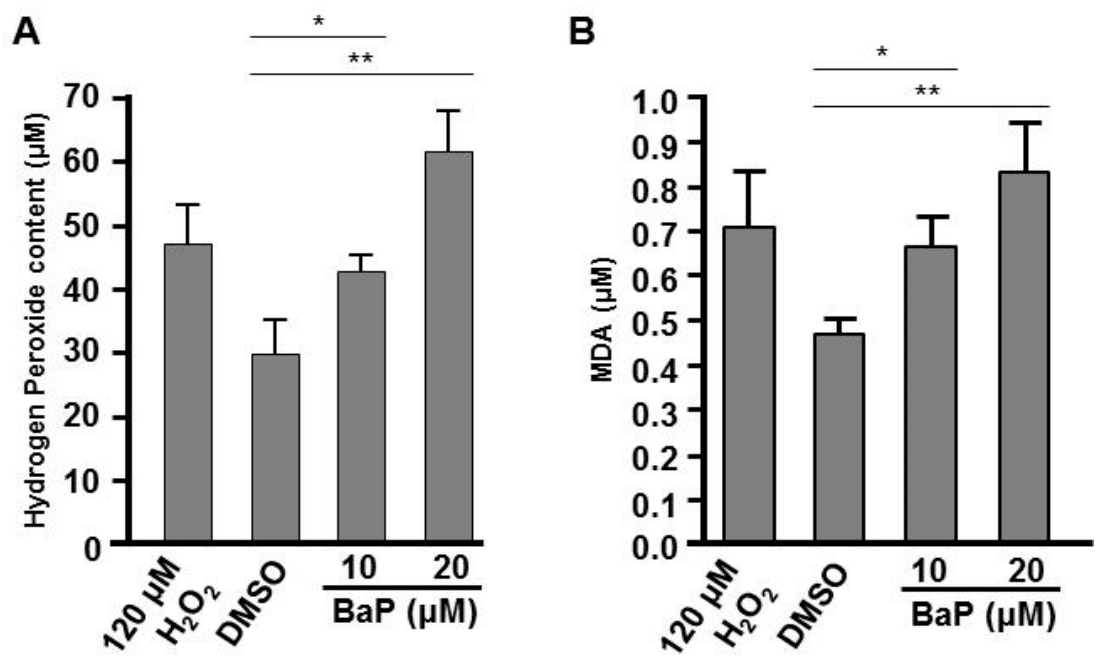

Figure 7. Exposure to $\mathrm{B}[\mathrm{a}] \mathrm{P}$ increases embryonic hydrogen peroxide and lipid peroxidation. (A) Embryonic hydrogen peroxide content was determined by the FOX assay and (B) the level of lipid peroxidation was examined by the malondialdehyde (MDA) assay. ${ }^{*} p<0.05,{ }^{* *} p<0.01$.

\section{Discussion and Conclusions}

There is increasing awareness of the relationship between environmental pollutants, oxidative stress and neurodegenerative diseases. In this study, we used zebrafish embryos to investigate the toxic effects of $\mathrm{B}[\mathrm{a}] \mathrm{P}$ and explore the association between its neural toxicity, the Hif-pathway and oxidative stress. Zebrafish embryos were developmentally exposed to B[a]P at 10 and $20 \mu \mathrm{M}$. Developing neural cells were monitored in $\mathrm{B}[\mathrm{a}] P$-exposed $\mathrm{Tg}$ (elavl3:EGFP) transgenic embryos, revealing the reductions in trigeminal ganglion cells in the head region and Rohon-Beard cells in the trunk. We noticed that the reduced cell levels were more significant in head and front-trunk than in the mid-trunk and tail (Figure 1). We further examined the developing neural cells by in situ hybridization for elavl3, shh and isl1; these results also revealed clear developmental toxicity to neural cells and showed more significant effects in the head and front trunk than in the posterior regions (Figures 2 and 3).

Our results also suggest that exposure to B[a]P at early embryonic stages results in the expression of neural regulatory genes in the head and front-trunk. In situ hybridization staining for shh indicated that its expression level and pattern was severely affected in the mid-diencephalic organizer, hypothalamus and basal plate brain regions, without obvious effects in the trunk regions (Figure 2A-G). During embryonic neurogenesis, shh is expressed in the developing hypothalamus and is essential 
for hypothalamic induction and mid-diencephalic organizer development [48-50]. Staining for isl1 expression also clearly revealed the effects of B[a]P toxicity on brain development. At $24 \mathrm{hpf}$, isl1 is normally specifically expressed in telencephalon, ventral thalamus, hypothalamus, epiphysis and posterior commissure regions of the developing brain (Figure $3 \mathrm{H})$. However, in $\mathrm{B}[\mathrm{a}] P$-treated embryos, the expression areas and intensity of isl 1 in these regions were dramatically reduced (Figure 3I,J). To explore when B[a]P toxicity is first observed, we further examined neural development in $\mathrm{B}[\mathrm{a}] P$-treated embryos at an earlier time-point. No developmental toxicity was observed in $\mathrm{B}[\mathrm{a}] P$-treated embryos at $12 \mathrm{hpf}$ (Figure 4). These results indicated that the neurotoxicity of B[a]P is likely to occur at embryonic stages later than $12 \mathrm{hpf}$.

Many reports have shown the induction of oxidative stress upon exposure to environmental toxins [51] or hypoxia [52]. Indeed, oxidative stress is arguably the most common toxic mechanism for environmental agents $[53,54]$. Hifs belong to the basic helix-loop-helix-PER-ARNT-SIM (bHLH-PAS) subfamily of bHLH transcription factors and are often centrally involved in the cellular response to oxygen levels. Our results indicated that the expression of hif $1 a$ and hif2a was dose-dependently reduced in $\mathrm{B}[\mathrm{a}] P$-treated embryos, suggesting the Hif pathway may be involved in the neurodevelopmental toxicity of B[a]P. During embryogenesis, Survivin is especially important in neural progenitors of mammalian and zebrafish embryos [55]. During brain development, survivin is highly expressed in neural progenitor cells and plays an essential role in the maintenance of developing neural cells [56]. Antisense morpholino-induced knockdown of the zebrafish Hif2a protein was shown to cause a deficit in survivin transcription, which abrogates neural cell development [28]. This mechanism may explain our observation that embryonic exposure of $\mathrm{B}[\mathrm{a}] \mathrm{P}$ dose-dependently reduced the expression of survivin in concert with hif1a and hif2a (Figure 5A,B and Figure 6M).

Epo is widely known for its role in erythropoiesis during embryogenesis and in adults. Many reports have shown that Epo signaling also plays an important role in the neuroprotection of the adult brain $[57,58]$ and neural development during embryogenesis $[59,60]$. During embryogenesis, the developing nervous system requires precise regulation of oxygen levels. Low levels of oxygen induce Hif gene expression, which enhances the expression of epo to regulate erythrogenesis [61]. Our results indicated that the expression levels of hif1 $a$ and $h i f 2 a$ were reduced in $\mathrm{B}[\mathrm{a}] P$-treated embryos. Consistently, the expression of epo also exhibited a dose-dependent reduction in $\mathrm{B}[\mathrm{a}] P$-treated embryos. These results suggest that embryonic exposure to $\mathrm{B}[\mathrm{a}] \mathrm{P}$ reduces Hif-mediated signaling, which may be responsible for the reduced expression of survivin and epo, resulting in defective neural development.

Inhibition of hif1a expression is known to enhance the generation of ROS and reduce the transcription of primary antioxidant enzymes, which can cause pathology in multiple organs [62]. Expression of ROS-related genes, calatase and sod1, was altered in B[a]P-treated embryos. Both Catalase and Sod1 participate in ROS detoxification. Sod1 is a cytosolic antioxidant enzyme that converts the highly reactive superoxide radical to $\mathrm{H}_{2} \mathrm{O}_{2}$, which can be eliminated by enzymes, such as Catalase. The induced expression of Sod 1 and reduced expression of Catalase suggested that embryonic exposure to $\mathrm{B}[\mathrm{a}] \mathrm{P}$ may increase the cellular level of $\mathrm{H}_{2} \mathrm{O}_{2}$. As predicted, the embryonic $\mathrm{H}_{2} \mathrm{O}_{2}$ level was dose-dependently induced after $\mathrm{B}[\mathrm{a}] \mathrm{P}$ exposure. While high levels of $\mathrm{H}_{2} \mathrm{O}_{2}$ are widely known to cause cytotoxic effects, many recent reports have shown that the molecule is also an important regulator of eukaryotic signal transduction $[63,64]$.

Surprisingly, the embryonic $\mathrm{H}_{2} \mathrm{O}_{2}$ level in $10 \mu \mathrm{M} B[\mathrm{a}] P$-treated embryos was similar to the positive control embryos treated with $120 \mu \mathrm{M} \mathrm{H}_{2} \mathrm{O}_{2}$. During zebrafish embryogenesis, dynamic changes in endogenous embryonic $\mathrm{H}_{2} \mathrm{O}_{2}$ level may play an important role in regulating proper embryogenesis [65]. Excessive cellular $\mathrm{H}_{2} \mathrm{O}_{2}$ results in lipid peroxidation, triggers cell death [66-68] and induces neutrophil infiltration, inflammation by modulating the immune system [69,70]. Exposure to $\mathrm{B}[\mathrm{a}] \mathrm{P}$ is known to play a role in lung carcinogenesis induced by tissue inflammation $[70,71]$. In current years, the potential neurotoxicity of $\mathrm{B}[\mathrm{a}] \mathrm{P}$ inducing oxidative stress-mediated neurotoxicity and causing behavioral alterations and oxidative stress in animal models was reported [72-74]. B[a]P can reach the encephalic central nervous tissues by crossing the blood-brain barrier [75-77]; this leads 
to increase nervous oxidative stress in the nervous system which in turn resulting in behavioral changes and alterations to the expression of antioxidant enzymes (e.g., superoxide dismutase, catalase and glutathione peroxidase and cellular lipid peroxidation [77,78]. Epidemiological studies have demonstrated that exposure to B[a]P causes neurological abnormalities such as cognitive impairment, learning difficulties, parasympathetic dysregulation and short-term memory loss [79-81]. Embryonic $\mathrm{B}[\mathrm{a}] \mathrm{P}$ exposure increases the risk of neural hypoplasia. Neural tube defects are the most common and severe congenital malformations due to the disturbance of normal neural tube closure during early embryogenesis. Maternal B[a]P exposure increases fetal neural tube defects, neural apoptosis and the expression of the oxidative stress related genes, cyp1a1, sod1 and sod2. Neural apoptosis and oxidative stress-related gene expression can be attenuated by ectopic supplementation of antioxidants, such as vitamin $\mathrm{E}$ or retinoic acid $[82,83]$. This shows that $\mathrm{B}[\mathrm{a}] \mathrm{P}$ exposure induces embryonic neural defects that may involve increased oxidative stress.

Based on our findings, we conclude that Hif signaling-mediated embryonic oxidative stress is likely to be involved in the developmental neurotoxicity of $\mathrm{B}[\mathrm{a}] \mathrm{P}$ and the tissue inflammation process. Therefore, our study further elucidates the molecular basis of B[a]P neurotoxicity during embryogenesis.

Supplementary Materials: The following are available online at http://www.mdpi.com/2076-3921/9/8/731/s1, Figure S1: Sense riboprobe serves as negative controls for in situ hybridization staining assay.

Author Contributions: W.-D.W., C.-H.H., T.-W.P. and Y.-R.C.; methodology, Y.-C.L., C.-Y.W., W.-D.W.; validation, W.-D.W., Y.-C.L.; formal analysis, Y.-C.L., W.-D.W., C.-H.H., T.-W.P. and Y.-R.C.; investigation, Y.-C.L. and W.-D.W.; writing-original draft preparation, C.-Y.W. and W.-D.W.; writing-Review and editing, Y.-C.L., C.-Y.W., W.-D.W., C.-H.H., T.-W.P. and Y.-R.C.; supervision, W.-D.W.; and Project Administration, W.-D.W. All authors have read and agreed to the published version of the manuscript.

Funding: This work was supported by the grants from Ministry of Science and Technology, Taiwan (MOST 105-2313-B-415-001-, MOST106-2313-B-415-001- and MOST 107-2313-B-415-001-).

Acknowledgments: We thank Taiwan Zebrafish Core Facility at the National Health Research Institutes (TZeTH) and at Academia Sinica (TZCAS), which are supported by grant MOST104-2321-B-001 -045 and MOST 108-2319-B-400-002 from the Ministry of Science and Technology (MOST), respectively. We are also grateful to M. Calkins for English editing.

Conflicts of Interest: The authors indicate no potential conflicts of interest.

\section{References}

1. Sasai, Y.; Lu, B.; Steinbeisser, H.; De Robertis, E.M. Regulation of neural induction by the Chd and Bmp-4 antagonistic patterning signals in Xenopus. Nature 1995, 376, 333-336. [CrossRef]

2. Linker, C.; Stern, C.D. Neural induction requires BMP inhibition only as a late step, and involves signals other than FGF and Wnt antagonists. Development 2004, 131, 5671-5681. [CrossRef]

3. Committee NRC. Polycyclic Aromatic Hydrocarbons: Evaluation of Sources and Effects; National Academies Press: Washington, DC, USA, 1983.

4. Guo, Z.; Lin, T.; Zhang, G.; Yang, Z.; Fang, M. High-resolution depositional records of polycyclic aromatic hydrocarbons in the central continental shelf mud of the East China Sea. Environ. Sci. Technol. 2006, 40, 5304-5311. [CrossRef]

5. Selkirk, J.K. Benzo[a]pyrene carcinogenesis: A biochemical selection mechanism. J. Toxicol. Environ. Health Part A 1977, 2, 1245-1258. [CrossRef]

6. Lindeman, T.E.; Poirier, M.C.; Divi, R.L. The resveratrol analogue, 2, 3' , 4, 5' -tetramethoxystilbene, does not inhibit CYP gene expression, enzyme activity and benzo[a]pyrene-DNA adduct formation in MCF-7 cells exposed to benzo[a]pyrene. Mutagenesis 2011, 26, 629-635. [CrossRef]

7. IARC. Ingested nitrate and nitrite, and cyanobacterial peptide toxins. In IARC Monographs on the Evaluation of Carcinogenic Risks to Humans; IARC: Lyon, France, 2010; Volume 94.

8. Hylland, K. Polycyclic Aromatic Hydrocarbon (PAH) Ecotoxicology in Marine Ecosystems. J. Toxicol. Environ. Health Part A 2006, 69, 109-123. [CrossRef]

9. Van De Wiele, T.; Vanhaecke, L.; Boeckaert, C.; Peru, K.; Headley, J.; Verstraete, W.; Siciliano, S. Human colon microbiota transform polycyclic aromatic hydrocarbons to estrogenic metabolites. Environ. Health Perspect. 2005, 113, 6-10. [CrossRef] 
10. Wu, J.; Ramesh, A.; Nayyar, T.; Hood, D.B. Assessment of metabolites and AhR and CYP1A1 mRNA expression subsequent to prenatal exposure to inhaled benzo(a)pyrene. Int. J. Dev. Neurosci. 2003, 21, 333-346. [CrossRef]

11. Davila, D.R.; Romero, D.L.; Burchiel, S.W. Human T cells are highly sensitive to suppression of mitogenesis by polycyclic aromatic hydrocarbons and this effect is differentially reversed by alpha-naphthoflavone. Toxicol. Appl. Pharmacol. 1996, 139, 333-341. [CrossRef]

12. Mendola, P.; Selevan, S.G.; Gutter, S.; Rice, D. Environmental factors associated with a spectrum of neurodevelopmental deficits. Ment. Retard. Dev. Disabil. Res. Rev. 2002, 8, 188-197. [CrossRef]

13. Min, L.; He, S.; Chen, Q.; Peng, F.; Peng, H.; Xie, M. Comparative proteomic analysis of cellular response of human airway epithelial cells (A549) to benzo(a)pyrene. Toxicol. Mech. Methods 2011, 21, 374-382. [CrossRef]

14. Wolterbeek, A.P.; Schoevers, E.J.; Rutten, A.A.; Feron, V.J. A critical appraisal of intratracheal instillation of benzo[a]pyrene to Syrian golden hamsters as a model in respiratory tract carcinogenesis. Cancer Lett. 1995, 89, 107-116. [CrossRef]

15. Jones, D.P. Extracellular Redox State: Refining the Definition of Oxidative Stress in Aging. Rejuvenation Res. 2006, 9, 169-181. [CrossRef]

16. Castro-Obregón, S.; Covarrubias, L. Role of retinoic acid and oxidative stress in embryonic stem cell death and neuronal differentiation. FEBS Lett. 1996, 381, 93-97. [CrossRef]

17. Hu, Q.; Khanna, P.; Wong, B.S.E.; Heng, Z.S.L.; Subhramanyam, C.S.; Thanga, L.Z.; Tan, S.W.S.; Baeg, G.H. Oxidative stress promotes exit from the stem cell state and spontaneous neuronal differentiation. Oncotarget 2017, 9, 4223-4238. [CrossRef]

18. Guillaumet-Adkins, A.; Yañez, Y.; Peris-Diaz, M.D.; Calabria, I.; Palanca-Ballester, C.; Sandoval, J. Epigenetics and Oxidative Stress in Aging. Oxidative Med. Cell. Longev. 2017, 2017, 1-8. [CrossRef]

19. Maluf, S.W.; Marroni, N.P.; Heuser, V.D.; Prá, D. DNA Damage and Oxidative Stress in Human Disease. BioMed Res. Int. 2013, 2013, 1-2. [CrossRef]

20. Neofytou, E.; Tzortzaki, E.G.; Chatziantoniou, A.; Siafakas, N.M. DNA Damage Due to Oxidative Stress in Chronic Obstructive Pulmonary Disease (COPD). Int. J. Mol. Sci. 2012, 13, 16853-16864. [CrossRef]

21. Tsutsui, H.; Kinugawa, S.; Matsushima, S. Oxidative stress and heart failure. Am. J. Physiol. Circ. Physiol. 2011, 301, H2181-H2190. [CrossRef]

22. Dennery, P.A. Oxidative stress in development: Nature or nurture? Free Radic. Boil. Med. 2010, 49, 1147-1151. [CrossRef]

23. Chen, X.; Guo, C.; Kong, J. Oxidative stress in neurodegenerative diseases. Neural Regen. Res. 2012, 7 , 376-385.

24. Chui, A.; Zhang, Q.; Dai, Q.; Shi, S.-H. Oxidative stress regulates progenitor behavior and cortical neurogenesis. Development 2020, 147, dev184150. [CrossRef]

25. Maxwell, P.; Wiesener, M.S.; Chang, G.-W.; Clifford, S.C.; Vaux, E.C.; Cockman, M.E.; Wykoff, C.C.; Pugh, C.W.; Maher, E.; Ratcliffe, P.J. The tumour suppressor protein VHL targets hypoxia-inducible factors for oxygen-dependent proteolysis. Nature 1999, 399, 271-275. [CrossRef]

26. Nanka, O.; Valasek, P.; Dvorakova, M.; Grim, M. Experimental hypoxia and embryonic angiogenesis. Dev. Dyn. 2006, 235, 723-733. [CrossRef]

27. Haase, V.H. Regulation of erythropoiesis by hypoxia-inducible factors. Blood Rev. 2013, 27, 41-53. [CrossRef]

28. Ko, C.-Y.; Tsai, M.-Y.; Tseng, W.-F.; Cheng, C.-H.; Huang, C.-R.; Wu, J.-S.; Chung, H.-Y.; Hsieh, C.-S.; Sun, C.; Hwang, S.-P.L.; et al. Integration of CNS survival and differentiation by HIF2 $\alpha$. Cell Death Differ. 2011, 18, 1757-1770. [CrossRef]

29. Kimmel, C.B.; Ballard, W.W.; Kimmel, S.R.; Ullmann, B.; Schilling, T.F. Stages of embryonic development of the zebrafish. Dev. Dyn. 1995, 203, 253-310. [CrossRef]

30. Thisse, C.; Thisse, B.; Schilling, T.F.; Postlethwait, J.H. Structure of the zebrafish snail1 gene and its expression in wild-type, spadetail and no tail mutant embryos. Development 1993, 119, 1203-1215.

31. Kaji, T.; Artinger, K.B. dlx3b and dlx4b function in the development of Rohon-Beard sensory neurons and trigeminal placode in the zebrafish neurula. Dev. Boil. 2004, 276, 523-540. [CrossRef]

32. Chandrasekhar, A.; Warren, J.T.; Takahashi, K.; E Schauerte, H.; Van Eeden, F.J.; Haffter, P.; Kuwada, J.Y. Role of sonic hedgehog in branchiomotor neuron induction in zebrafish. Mech. Dev. 1998, 76, 101-115. [CrossRef] 
33. Paffett-Lugassy, N.; Hsia, N.; Fraenkel, P.G.; Paw, B.H.; Leshinsky, I.; Barut, B.; Bahary, N.; Caro, J.; Handin, R.; Zon, L.I. Functional conservation of erythropoietin signaling in zebrafish. Blood 2007, 110, 2718-2726. [CrossRef] [PubMed]

34. Delvaeye, M.; De Vriese, A.; Zwerts, F.; Betz, I.; Moons, M.; Autiero, M.; Conway, E.M. Role of the 2 zebrafish survivin genes in vasculo-angiogenesis, neurogenesis, cardiogenesis and hematopoiesis. BMC Dev. Boil. 2009, 9, 25. [CrossRef] [PubMed]

35. Jiang, Z.-Y.; Hunt, J.V.; Wolff, S.P. Ferrous ion oxidation in the presence of xylenol orange for detection of lipid hydroperoxide in low density lipoprotein. Anal. Biochem. 1992, 202, 384-389. [CrossRef]

36. Wikenheiser, J.; Karunamuni, G.; Sloter, E.; Walker, M.K.; Roy, D.; Wilson, D.L.; Watanabe, M. Altering HIF-1 $\alpha$ through 2, 3, 7, 8-Tetrachlorodibenzo-p-Dioxin (TCDD) Exposure Affects Coronary Vessel Development. Cardiovasc. Toxicol. 2012, 13, 161-167. [CrossRef]

37. Tomita, S.; Ueno, M.; Sakamoto, M.; Kitahama, Y.; Ueki, M.; Maekawa, N.; Sakamoto, H.; Gassmann, M.; Kageyama, R.; Ueda, N.; et al. Defective Brain Development in Mice Lacking the Hif- $1 \alpha$ Gene in Neural Cells. Mol. Cell. Boil. 2003, 23, 6739-6749. [CrossRef]

38. Alnaeeli, M.; Wang, L.; Piknova, B.; Rogers, H.; Li, X.; Noguchi, C.T. Erythropoietin in Brain Development and Beyond. Anat. Res. Int. 2012, 2012, 1-15. [CrossRef]

39. Wheeler, J.A.; Clinkenbeard, E.L. Regulation of Fibroblast Growth Factor 23 by Iron, EPO, and HIF. Curr. Mol. Boil. Rep. 2019, 5, 8-17. [CrossRef]

40. Adelman, D.M.; Maltepe, E.; Simon, M.C. HIF-1 is Essential for Multilineage Hematopoiesis in the Embryo. Retinal Degener. Dis. 2002, 475, 275-284.

41. Zhou, D.; Han, S.; Yan, T.; Long, C.; Xu, J.; Zheng, P.; Chen, Z.; Jia, G. Toxicity of Titanium Dioxide Nanoparticles Induced by Reactive Oxygen Species. React. Oxyg. Species 2019, 8, 267-275.

42. Parke, D.V.; Sapota, A. Chemical toxicity and reactive oxygen species. Int. J. Occup. Med. Environ. Health 1996, 9, 331-340.

43. Buonocore, G.; Perrone, S.; Tataranno, M.L. Oxygen toxicity: Chemistry and biology of reactive oxygen species. Semin. Fetal Neonatal Med. 2010, 15, 186-190. [CrossRef] [PubMed]

44. Spagnuolo, M.S.; Sarubbi, F.; Rossetti, C.; Grazioli, G.; Di Meo, G.P.; Iannuzzi, L. Effect of dioxin exposure on several indices of blood redox status in lactating buffalo cows. J. Dairy Res. 2011, 78, 154-159. [CrossRef] [PubMed]

45. Sokol, R.J.; Devereaux, M.W.; Traber, M.G.; Shikes, R.H. Copper toxicity and lipid peroxidation in isolated rat hepatocytes: Effect of vitamin E. Pediatr. Res. 1989, 25, 55-62. [CrossRef] [PubMed]

46. Thurman, R.G.; Oshino, N.; Chance, B. The Role of Hydrogen Peroxide Production and Catalase in Hepatic Ethanol Metabolism. Retinal Degener. Dis. 1975, 59, 163-183.

47. Buettner, G.R. Superoxide dismutase in redox biology: The roles of superoxide and hydrogen peroxide. Anti-Cancer Agents Med. Chem. 2011, 11, 341-346. [CrossRef]

48. Blaess, S.; Szabo, N.; Haddad-Tóvolli, R.; Zhou, X.; Alvarez-Bolado, G. Sonic hedgehog signaling in the development of the mouse hypothalamus. Front. Neuroanat. 2015, 8, 156. [CrossRef]

49. Corman, T.S.; Bergendahl, S.E.; Epstein, D.J. Distinct temporal requirements for Sonic hedgehog signaling in development of the tuberal hypothalamus. Development 2018, 145, dev167379. [CrossRef]

50. Scholpp, S.; Lumsden, A. Building a bridal chamber: Development of the thalamus. Trends Neurosci. 2010, 33, 373-380. [CrossRef]

51. Samet, J.M.; Wages, P.A. Oxidative Stress from Environmental Exposures. Curr. Opin. Toxicol. 2018, 7, 60-66. [CrossRef]

52. Cervellati, F.; Cervellati, C.; Romani, A.; Cremonini, E.; Sticozzi, C.; Belmonte, G.; Pessina, F.; Valacchi, G. Hypoxia induces cell damage via oxidative stress in retinal epithelial cells. Free Radic. Res. 2014, 48, 303-312. [CrossRef]

53. Al-Gubory, K.H. Multiple exposures to environmental pollutants and oxidative stress: Is there a sex specific risk of developmental complications for fetuses? Birth Defects Res. Part C Embryo Today Rev. 2016, 108, 351-364.

54. Rossignol, D.A.; Frye, R.E. A review of research trends in physiological abnormalities in autism spectrum disorders: Immune dysregulation, inflammation, oxidative stress, mitochondrial dysfunction and environmental toxicant exposures. Mol. Psychiatry 2012, 17, 389-401. [CrossRef] 
55. Adida, C.; Crotty, P.L.; McGrath, J.; Berrebi, D.; Diebold, J.; Altieri, D.C. Developmentally regulated expression of the novel cancer anti-apoptosis gene survivin in human and mouse differentiation. Am. J. Pathol. 1998, $152,43-49$.

56. Jiang, Y.; De Bruin, A.; Caldas, H.; Fangusaro, J.; Hayes, J.; Conway, E.M.; Robinson, M.L.; Altura, R.A. Essential Role for Survivin in Early Brain Development. J. Neurosci. 2005, 25, 6962-6970. [CrossRef] [PubMed]

57. Zakharova, E.T.; Sokolov, A.V.; Pavlichenko, N.; Kostevich, V.A.; Abdurasulova, I.N.; Chechushkov, A.V.; Voynova, I.V.; Elizarova, A.Y.; Kolmakov, N.N.; Bass, M.G.; et al. Erythropoietin and Nrf2: Key factors in the neuroprotection provided by apo-lactoferrin. BioMetals 2018, 31, 425-443. [CrossRef] [PubMed]

58. Digicaylioglu, M.; Lipton, S.A. Erythropoietin-mediated neuroprotection involves cross-talk between Jak2 and NF- $\kappa$ B signalling cascades. Nature 2001, 412, 641-647. [CrossRef]

59. Yu, X.; Shacka, J.J.; Eells, J.B.; Suarez-Quian, C.; Przygodzki, R.M.; Beleslin-Cokic, B.; Lin, C.-S.; Nikodem, V.M.; Hempstead, B.; Flanders, K.C.; et al. Erythropoietin receptor signalling is required for normal brain development. Development 2002, 129, 505-516.

60. Wakhloo, D.; Scharkowski, F.; Curto, Y.; Butt, U.J.; Bansal, V.; Steixner-Kumar, A.A.; Wüstefeld, L.; Rajput, A.; Arinrad, S.; Zillmann, M.R.; et al. Functional hypoxia drives neuroplasticity and neurogenesis via brain erythropoietin. Nat. Commun. 2020, 11, 1-12. [CrossRef] [PubMed]

61. Bonkowsky, J.L.; Son, J.-H. Hypoxia and connectivity in the developing vertebrate nervous system. Dis. Model. Mech. 2018, 11, dmm037127. [CrossRef] [PubMed]

62. Scortegagna, M.; Ding, K.; Oktay, Y.; Gaur, A.; Thurmond, F.; Yan, L.J.; Marck, B.T.; Matsumoto, A.M.; Shelton, J.M.; Richardson, J.A.; et al. Multiple organ pathology, metabolic abnormalities and impaired homeostasis of reactive oxygen species in Epas1-/-mice. Nat. Genet. 2003, 35, 331-340. [CrossRef] [PubMed]

63. Rieger, S.; Sagasti, A. Hydrogen peroxide promotes injury-induced peripheral sensory axon regeneration in the zebrafish skin. PLoS ONE Biol. 2011, 9, e1000621. [CrossRef] [PubMed]

64. Veal, E.A.; Day, A.M.; Morgan, B.A. Hydrogen Peroxide Sensing and Signaling. Mol. Cell 2007, 26, 1-14. [CrossRef] [PubMed]

65. Rampon, C.; Volovitch, M.; Joliot, A.; Vriz, S. Hydrogen Peroxide and Redox Regulation of Developments. Antioxidants 2018, 7, 159. [CrossRef]

66. Tomita, K.; Takashi, Y.; Ouchi, Y.; Kuwahara, Y.; Igarashi, K.; Nagasawa, T.; Nabika, H.; Kurimasa, A.; Fukumoto, M.; Nishitani, Y.; et al. Lipid peroxidation increases hydrogen peroxide permeability leading to cell death in cancer cell lines that lack mtDNA. Cancer Sci. 2019, 110, 2856-2866. [CrossRef] [PubMed]

67. Kellogg, E.W.; Fridovich, I. Superoxide, hydrogen peroxide, and singlet oxygen in lipid peroxidation by a xanthine oxidase system. J. Boil. Chem. 1975, 250, 8812-8817.

68. McNeill-Blue, C.; Wetmore, B.A.; Sanchez, J.F.; Freed, W.J.; Merrick, B.A. Apoptosis mediated by p53 in rat neural AF5 cells following treatment with hydrogen peroxide and staurosporine. Brain Res. 2006, 1112, 1-15. [CrossRef]

69. Reis, A.C.; Alessandri, A.L.; Athayde, R.M.; Perez, D.A.; Vago, J.P.; Ávila, T.V.; Ferreira, T.P.T.; De Arantes, A.C.S.; Coutinho, D.; Rachid, M.A.; et al. Induction of eosinophil apoptosis by hydrogen peroxide promotes the resolution of allergic inflammation. Cell Death Dis. 2015, 6, e1632. [CrossRef]

70. Wittmann, C.; Chockley, P.; Singh, S.K.; Pase, L.; Lieschke, G.J.; Grabher, C. Hydrogen Peroxide in Inflammation: Messenger, Guide, and Assassin. Adv. Hematol. 2012, 2012, 1-6. [CrossRef]

71. Qamar, W.; Khan, A.Q.; Khan, R.; Lateef, A.; Tahir, M.; Rehman, M.U.; Ali, F.; Sultana, S. Benzo(a)pyrene-induced pulmonary inflammation, edema, surfactant dysfunction, and injuries in rats: Alleviation by farnesol. Exp. Lung Res. 2011, 38, 19-27. [CrossRef]

72. Das, S.K.; Patri, M. Neuropeptide Y expression confers benzo[a]pyrene induced anxiolytic like behavioral response during early adolescence period of male Wistar rats. Neuropeptides 2017, 61, 23-30. [CrossRef]

73. Mohanty, R.; Das, S.K.; Singh, N.R.; Patri, M. Withania somnifera Leaf Extract Ameliorates Benzo[a]pyrene-Induced Behavioral and Neuromorphological Alterations by Improving Brain Antioxidant Status in Zebrafish (Danio rerio). Zebrafish 2016, 13, 188-196. [CrossRef] [PubMed]

74. Patel, B.; Das, S.K.; Patri, M. Neonatal Benzo[a]pyrene Exposure Induces Oxidative Stress and DNA Damage Causing Neurobehavioural Changes during the Early Adolescence Period in Rats. Dev. Neurosci. 2016, 38, 150-162. [CrossRef] [PubMed]

75. Das, M.; Seth, P.K.; Mukhtar, H. Distribution of benzo(a)pyrene in discrete regions of rat brain. Bull. Environ. Contam. Toxicol. 1985, 35, 500-504. [CrossRef] [PubMed] 
76. Grova, N.; Schroeder, H.; Farinelle, S.; Prodhomme, E.; Valley, A.; Muller, C.P. Sub-acute administration of benzo[a]pyrene $(\mathrm{B}[\mathrm{a}] \mathrm{P})$ reduces anxiety-related behaviour in adult mice and modulates regional expression of N-methyl-d-aspartate (NMDA) receptors genes in relevant brain regions. Chemosphere 2008, 73, S295-S302. [CrossRef]

77. Saunders, C.R.; Das, S.K.; Ramesh, A.; Shockley, D.C.; Mukherjee, S. Benzo(a)pyrene-induced acute neurotoxicity in the F-344 rat: Role of oxidative stress. J. Appl. Toxicol. 2006, 26, 427-438. [CrossRef]

78. Cheng, S.-Q.; Xia, Y.-Y.; He, J.-L.; Liu, X.-Q.; Chen, X.; Ding, Y.-B.; Wang, Y.-X.; Peng, B.; Tu, B.-J. Neurotoxic effect of subacute benzo(a)pyrene exposure on gene and protein expression in Sprague-Dawley rats. Environ. Toxicol. Pharmacol. 2013, 36, 648-658. [CrossRef]

79. Dayal, H.; Gupta, S.; Trieff, N.; Maierson, D.; Reich, D. Symptom Clusters in a Community with Chronic Exposure to Chemicals in Two Superfund Sites. Arch. Environ. Health Int. J. 1995, 50, 108-111. [CrossRef]

80. Zhang, W.; Tian, F.; Zheng, J.; Li, S.; Qiang, M. Chronic Administration of Benzo(a)pyrene Induces Memory Impairment and Anxiety-Like Behavior and Increases of NR2B DNA Methylation. PLoS ONE 2016, 11, e0149574. [CrossRef]

81. Youbin, Q.; Chengzhi, C.; Yan, T.; Xuejun, J.; Chongying, Q.; Bin, P.; Tu, B. The synergistic effect of benzo[a]pyrene and lead on learning and memory of mice. Toxicol. Ind. Health 2012, 29, 387-395. [CrossRef]

82. Lin, S.; Ren, A.; Wang, L.; Huang, Y.; Wang, Y.; Wang, C.; Greene, N.D. Oxidative Stress and Apoptosis in Benzo[a]pyrene-Induced Neural Tube Defects. Free Radic. Boil. Med. 2018, 116, 149-158. [CrossRef]

83. Mohanty, R.; Das, S.K.; Patri, M. Modulation of Benzo[a]Pyrene Induced Anxiolytic-Like Behavior by Retinoic Acid in Zebrafish: Involvement of Oxidative Stress and Antioxidant Defense System. Neurotox. Res. 2017, 31, 493-504. [CrossRef] [PubMed]

(C) 2020 by the authors. Licensee MDPI, Basel, Switzerland. This article is an open access article distributed under the terms and conditions of the Creative Commons Attribution (CC BY) license (http://creativecommons.org/licenses/by/4.0/). 